\title{
Primary Tracheal Reconstruction in Cut Throat Injury of a 4 Years Old Child
}

\author{
Suman Arasikere Panchappa*, Rajaganesh Kuttuvu Swamirao, Dhinakaran Natarajan \\ Department of ENT, Madurai Medical College, Madurai, India \\ Email: ${ }^{*}$ rajsuman91@yahoo.com
}

Received 11 April 2014; revised 10 May 2014; accepted 9 June 2014

Copyright (C) 2014 by authors and Scientific Research Publishing Inc.

This work is licensed under the Creative Commons Attribution International License (CC BY). http://creativecommons.org/licenses/by/4.0/

(c) (i) Open Access

\begin{abstract}
Cut throat injuries in children are rare, but they constitute a significant management challenge. Such injuries are rarely reported in the literature. Evaluation and treatment of such injuries is a tough task. Cervical tracheal injuries are relatively uncommon and are frequently associated with esophageal, vascular or spinal injuries. We hereby report a case of cut throat injury with incomplete transection of trachea and its management in a four years old male child.
\end{abstract}

\section{Keywords}

\section{Paediatric Cut Throat, Homicide, Tracheal Transection, Primary Tracheal Reconstruction}

\section{Introduction}

A cut throat injury which is inflicted by sharp objects such as knife, razor, glass pieces, etc. may be superficial or penetrating. The cut throat injury may involve soft tissue, cartilage, bones or neurovascular bundles. In a case of cut throat injury, there may be possibility of injury to the vital structures that may become rapidly fatal from profuse haemorrhage by damaged major blood vessels, air embolism or airway obstruction.

\section{Case Report}

A four years old male child was received at ENT department of Madurai medical college at 5:25 am from Srivalliputhur government hospital, with the history of slashing his throat by his father with a sickle at 3:00 am on the same day. Father was a known patient of psychiatric illness on irregular treatment. Child was immobilized with chest and neck splint. On admission child was conscious. There was no respiratory distress, noisy breathing or cyanosis. Child was breathing from the cut stoma. There was no active bleeding or aspiration. Bilateral caro-

\footnotetext{
*Corresponding author.
}

How to cite this paper: Panchappa, S.A., Swamirao, R.K. and Natarajan, D. (2014) Primary Tracheal Reconstruction in Cut Throat Injury of a 4 Years Old Child. Case Reports in Clinical Medicine, 3, 361-363. 
tids were palpable above the cut. No neurological deficit present. Child's pulse rate was 134/min. Blood pressure was $90 / 60 \mathrm{~mm}$ of $\mathrm{Hg}$. $\mathrm{SpO}_{2}-98 \%$ in room air.

Immediate resuscitation started. Emergency wound exploration and primary closure of the trachea along with tracheostomy was planned under general anaesthesia. Under GA with endotracheal intubation, an uncompromised airway secured.

Wound examination under GA done. A horizontal contused lacerated wound of $10 \mathrm{~cm} \times 2 \mathrm{~cm}$ in the anterior part of the neck just above the suprasternal notch, extending between two sternomastoid muscles falling in ZONE 1 present [1].

- It was cutting through the skin, subcutaneous tissue, infrahyoid muscles, medial half of both the SCM.

- Trachea cut between 3rd and 4th tracheal rings for about 270 degree. Sparing the post wall of trachea.

- The carotids, IJV, thyroid gland, pharynx, oesophagus narrowly missed the injury.

Thorough betadine washes given. As there was clean cut ends of trachea, almost like a surgical cut and approximation was fair enough, on table decision of abandoning tracheostomy was taken. Transected trachea was sutured extramucosaly with interrupted 3 - 0 vicryl taken through perichondrium to perichondrium externally [2]. Sutures placed at an interval of $3-4 \mathrm{~mm}$. Cut ends of infrahyoid muscles sutured and sternomastoid muscles sutured. Wound closed in layers with Drain. Skin closed by subcuticular sutures.

Child was sedated, paralysed and shifted to PICU for ventilation: PR-120/min, RR-28/min, $\mathrm{SpO}_{2}-99 \%$ with $\mathrm{FiO}_{2}-100 \%$. In PICU connected to mechanical ventilator, SIMV-VC mode, IV cefot axime, amikacin, metrogyl started pre op and continued post op along with analgesics and dexamethasone.

On post operative day 1 , child self-extubated. Child was comfortable with no sridor and excellent voice production. Oxygen support through nasalcanula given. There was no soakage of dressing, no air leak and no surgical emphysema. On day 2 shifted to ENT ward and on day 3 drain removed, when there was no collection. Days 4, 5, 6 went uneventful. On day 7 sutures removed and Video laryngoscopic examination was normal. Child was discharged on day 8. On discharge child was near normal returning to daily routines.

\section{Discussion}

Penetrating neck injury constitutes 5\% - 10\% of all trauma cases. Three types of cut throat injuries are suicidal, homicidal and accidental. Suicidal cut throat injuries are more common. Male to female ratio is 2:1. Most common in young adults from rural area. Risk factors are mental illness, socio demographic status, familial and situational. The diagnosis is based on good data and clinical checkup [3].

Tracheal trauma is an uncommon occurrence in children because of their anatomy. Their short neck, increased elasticity of tissues, and compressibility of the upper sternal area provide for the ability to absorb blunt forces without trauma. Tracheal disruption is a rare occurrence and is seen in only $14 \%$ of penetrating neck trauma cases. In general, there is good bony protection of the trachea, but the cervical trachea is exposed anteriorly and laterally. Lesions at this site are not common. This is probably because the lower jaw affords some protection and because the trachea itself is elastic and mobile [4] [5].

The neck injuries posses a great challenge. The Neck contains vital structures like neurovascular bundles, pharynx, oesophagus, larynx, trachea present in small confined unprotected area. Hence these injuries are life threatening and present as emergencies. Neck is divided into ZONES which helps to assess the injuries [6] [7].

The assessment of the patient begins with the ABC of the resuscitation clearing the airway, evaluating breathing and circulation securing an uncompromised airway by ET tube or tracheostomy cervical spine stabilization assessing the injury and repair of the injury. The site of the injury suggests zone \& structures involved. Injuries to the larynx and trachea can be asymptomaticor present as hoarseness, stridor, or dyspnea secondary to airway compression or aspiration of blood. Bubbling of air through the neck indicates penetrating injury of larynx \& or trachea. Injury to the great vessels causes visible external blood loss, neck hematoma formation and shock. Retropharyngeal air in lateral neck X-ray indicates injury to pharynx or Oesophagus.

\section{Conclusion}

Every case should be assessed individually. Any penetrating injury in larynx \& trachea, repair is done primarily following a tracheostomy. In our case, considering the injury \& age of the patient tracheostomy is not done during repair. Primary airway repair without tracheostomy is still possible, when injuries are minimal \& reparable to near anatomy [8]-[10]. 


\section{References}

[1] Fagan, J.J. and Nicol, A.J. (2008) Neck Trauma, Scott Browns Otorhinolaryngology and Head and Neck Surgery. 7th Edition, Vol. 2, Hodder Arnold, London, 1766-1776.

[2] Joshi, S.S., Jagade, M., Nichalani, S., Bage, S., Agarwal, S. and Pangam, N. (2013) Technicality of Managing Cut Throat Injury. International Journal of Otolaryngology and Head \& Neck Surgery, 2, 11-12. http://dx.doi.org/10.4236/ijohns.2013.21004

[3] Gilyoma, J.M., Hauli, K.A. and Chalya, P.L. (2014) Cut Throat Injuries at a University Teaching Hospital in Northwestern Tanzania: A Review of 98 Cases. BMC Emergency Medicine, 14, 1.

[4] Barrett, E. (2011) Management of a Traumatic Tracheal Tear: A Case Report. AANA Journal, 79, 468-470. www.aana.com/aanajournalonline.aspx

[5] Bertelsen, S. and Howitz, P. (1972) Injuries of the Trachea and Bronchi. Department of Surgery D, Rigshospitalet, and the University Institute of Forensic Medicine, Copenhagen.

[6] Aich, M., Alam, K., Talukder, D.C., Sarder, R., Fakir, A.Y. and Hossain, M. (2011) Cut Throat Injury: Review of 67 Cases. Bangladesh Journal of Otorhinolaryngology, 17, 5-13.

[7] Adoga, A.A., Ma’an, N.D., Embu, H.Y. and Obindo, T.J. (2010) Management of Suicidal Cut Throat Injuries in a Developing Nation: Three Case Report. Cases Journal, 3, 65. http://dx.doi.org/10.1186/1757-1626-3-65

[8] Gorosh, L.R., Ingaramo, O., Nelson, D., Vohra, M. and Ciccolo, M.L. (2014) Spontaneous Tracheal Rupture: A Case Report. The Journal of Emergency Medicine, 46, 31-33.

[9] Hamid, U.I. and Jones, J.M. (2013) Combined Tracheoesophageal Transection after Blunt Neck Trauma. Journal of Emergencies, Trauma and Shock, 6, 117-122.

[10] Adoga, A.A. (2012) Suicidal Cut Throat Injuries: Management Modalities. Department of Ear, Nose, Throat/Head and Neck Surgery, University of Jos and Jos University Teaching Hospital, Nigeria. 
Scientific Research Publishing (SCIRP) is one of the largest Open Access journal publishers. It is currently publishing more than 200 open access, online, peer-reviewed journals covering a wide range of academic disciplines. SCIRP serves the worldwide academic communities and contributes to the progress and application of science with its publication.

Other selected journals from SCIRP are listed as below. Submit your manuscript to us via either submit@scirp.org or Online Submission Portal.
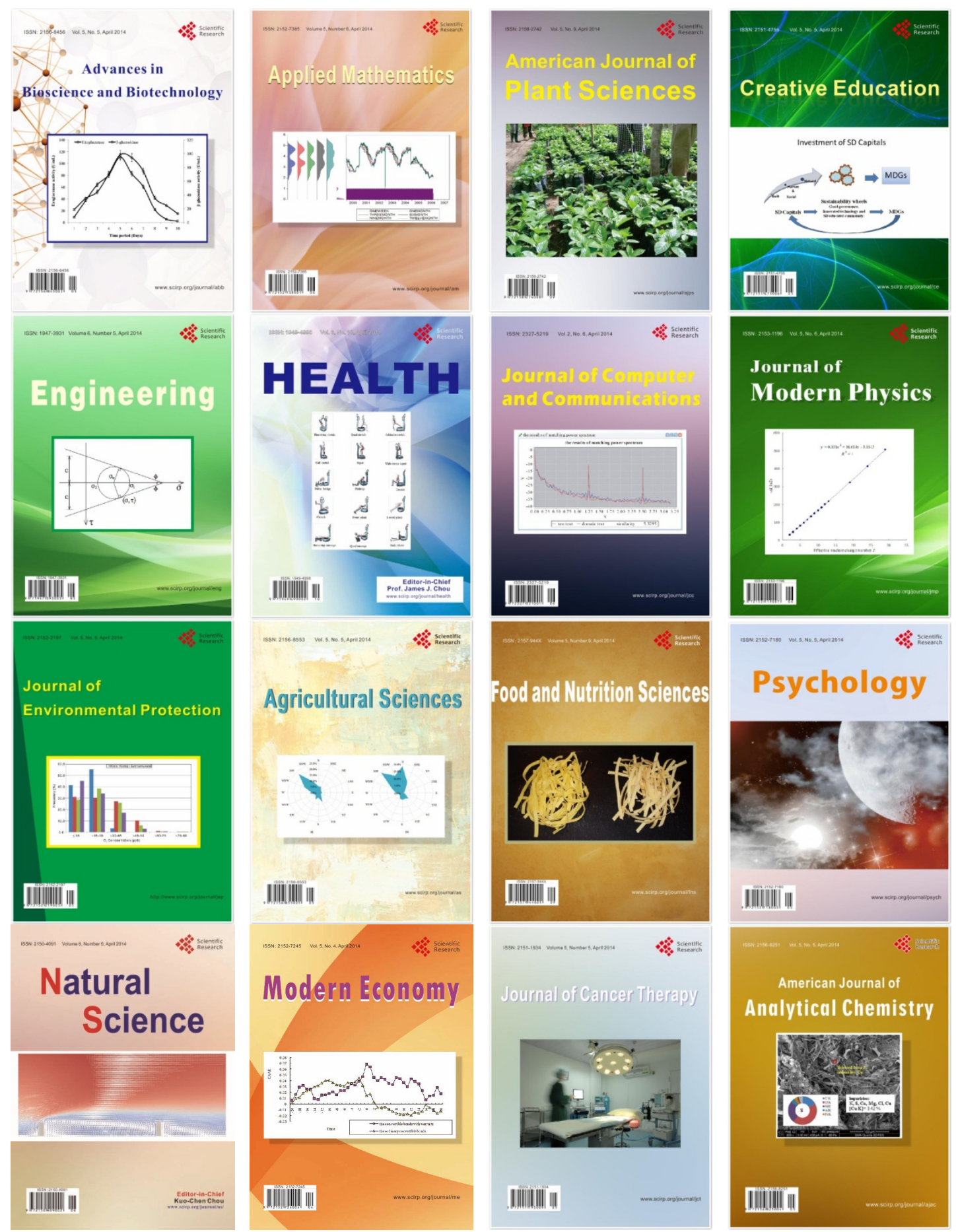